\title{
МЕТЕОРОЛОГІЧНІ ЗНАННЯ ТА ВІРУВАННЯ ЖИТЕЛІВ ПОЛІССЯ: УКРАЇНСЬКО-БІЛОРУСЬКІ ПАРАЛЕЛІ
}

\author{
О. О. Васянович
}

Васянович О. О. Метеорологічні знання та вірування жителів Полісся: українсько-білоруські паралелі. У статті на основі сучасних польових та друкованих матеріалів, розглядаються спільні та відмінні риси короткотермінових, довгострокових прикмет та ірраціональних способів впливу на погоду. Виявляється багато схожих елементів, сформованих у єдиних природно-кліматичних та національно-культурних умовах.

Ключові слова: народна метеорологія; короткотермінові прикмети; довгострокові прикмети; магія; трансформації; Полісся.

Васянович $A$. А. Метеорологические знания и верования жителей Полесья: украинскобелорусские параллели. В статье на основе современных полевых и печатных материалов рассматриваются общие и отличные черты кратковременных, долгосрочных примет и иррациональные способы влияния на погоду. Обнаружено много схожих элементов, сформированных в единых природно-климатических и национально-культурных условиях.

Ключевые слова: народная метеорология; краткосрочные приметы; долгосрочные приметы; магия; трансформации; Полесье.

Vasianovych $O$. O. Meteorological Knowledge and Beliefs of the Polissya residents: UkrainianBelarusian Parallels. Based on the modern field and printed materials it is considered common features of short-term, long-term signs and irrational ways to influence the weather. It turns out many similar elements formed in uniform natural and climatic as well as national and cultural conditions.

Keywords: folk meteorology; long-term signs; short-term signs; magic events; transformation; Polissya region.

Народна метеорологія, яка являє собою сукупність прикмет, що пов'язані з прогнозуванням погоди та різноманітних магічних методів впливу на несприятливі погодні явища, - невід’ємний елемент системи народних знань та вірувань поліщуків". Полісся справедливо оцінюється як одна 3 архаїчних зон слов'янського світу. Саме поліські свідчення про матеріальну і духовну культуру, мову, громадське і сімейне співіснування тощо часто служать для славістів відправною точкою у реконструкції найдавніших етапів історії слов'ян.

Події, які відбулися в суспільно-політичному, соціально-економічному та культурному житті білорусів та українців у XX - на початку XXI ст., стали могутнім фактором глибоких і всебічних змін їхнього світогляду. Прискорення процесу зникнення народної культури посилилося після аварії на Чорнобильській АЕС, коли радіаційного ураження зазнали більш як 145 тис. км² території України, Республіки Білорусь та Російської Федерації. Переважна більшість забруднень припала на Брестську, Гомельську, Волинську, Рівненську, Житомирську, Київську, та Чернігівську області, які належать до історико-етнографічного регіону Полісся. Після аварії зона відчуження та зона безумовного (обов'язкового) відселення назавжди перестали існувати як цілісний етнокультурний ареал; руйнівні процеси торкнулися й зони добровільного відселення. Внаслідок евакуації та подальшого переселення в способі життя та самосвідомості людей відбулися кардинальні зміни. Незворотна міграція сільських жителів, особливо молоді, призводить до відсутності звичного способу

\footnotetext{
* Тут і далі термін «поліщуки» вживається нами для позначення жителів Полісся, які мешкають як в Україні, так і Білорусі (на теренах Білорусі «палєшукі/палєщукі»). Вони близькі між собою, але не тотожні в мовно-культурному плані, їхня культура має низку особливостей, які ріднять перших з українцями, а других - із білорусами. Докладніше див. Балушок В. Г. Поліщуки // Енциклопедія історії України. К., 2011. Т. 8: Па - Прик. С. 341-342.
} 
передачі народної культури від старшого покоління до молодшого не лише в радіаційно уражених районах, а й по всьому Поліссю та інших історико-етнографічних регіонах. Це посилює тенденції суттєвих змін традиційного способу життя, шкали цінностей, культурних орієнтирів.

Тому збір та збереження різних складових етнічної культури нині залишається одним із найголовніших завдань етнологічної науки. Народні знання внаслідок трансформаційних процесів, розвитку освіти, загального піднесення культурного рівня поліщуків зазнають чи не найбільших нівелювань. Народна метеорологія, на відміну від метрології, астрономії, ще досить міцно зберігається у пам'яті старожилів, оскільки активно використовується у господарському житті та покликана забезпечувати добробут людини.

Мета нашого дослідження: на основі науково-критичного опрацювання друкованих матеріалів і польових записів, зібраних автором протягом 2002-2015 років у автентичних селах Українського Полісся та серед пересенців з зони відчуження, охарактеризувати метеорологічні знання та вірування поліщуків, звернувши увагу на їхні спільні та відмінні риси у білорусів та українців.

Метеорологічні прикмети наприкінці XIX - на початку XX ст. записували етнографи та фольклористи серед українців ${ }^{1}$ і білорусів ${ }^{2}$. Протягом останніх років у Білорусі було перевидано переклади деяких праць, опублікованих на початку XX ст. ${ }^{3}$. Деякі з цих свідчень стосуються поліського регіону, проте тогочасні записи хибують надто узагальненими географічними прив'язками.

У радянський період етнологи лише епізодично студіювали народні знання, зокрема метеорологічні. Своєрідним підсумком наукових пошуків українських та білоруських учених стала історико-етнографічна монографія «Общественный, семейный быт и духовная культура населения Полесья», присвячена проблемі народної духовної культури Українського та Білоруського Полісся 4 . Народну метеорологію Українського Полісся досліджувала О. Федорів, котра зібрала значну частину польових матеріалів у Волинській та Рівненській областях ${ }^{5}$.

Неабиякий внесок щодо аналізу народних метеорологічних знань та вірувань поліщуків зробили російські дослідники, зокрема співробітники Інституту слов'янознавства та балканістики АН СРСР М. Толстой та С. Толста. Упродовж 1970-1980-х рр. вони організували експедиції для збирання та систематизації польового матеріалу, що пізніше було апробовано у численних студіях, присвячених духовній культурі слов'янства ${ }^{6}$. Поліські матеріали займають вагоме місце і в сучасних дослідження російських науковців ${ }^{7}$.

Нинішні етнологічні студії у вітчизняній науці засвідчують різноманітний науковий інтерес до різних галузей народних знань Полісся. Зокрема, ми вже багато років досліджуємо метеорологічні знання та вірування поліщуків, звертаючи увагу як на прогнозування погоди, так і на магічні впливи на неї під час природних стихій, а саме: засухи, зливи, граду ${ }^{8}$. Чимало статей за власними польовими матеріалами оприлюднила волинська дослідниця Світлана Чибирак'.

Орієнтація на спостереження за погодними явищами, які впливають на господарство і життєдіяльність в цілому, визначила специфіку всього масиву метеорологічних передбачень поліщуків як в області прогнозів довгострокових (на період від кількох днів до кількох сезонів), так і короткотермінових (на найближчий час). Усе це пізніше проходило тривалу перевірку й у випадку успішного результату залучалося до практичного життєвого досвіду наших пращурів. Таким чином формувалися метеорологічні прикмети, які базуються на колективному досвіді і фіксуються в колективній пам'яті народів. Такого роду орієнтація, приурочена до природнокліматичних умов певного регіону, дає можливість порівняти народні неінструментальні метеорологічні передбачення з сучасними метеорологічними прогнозами.

Короткотермінові передбачення погоди поліщуки пов'язували в основному, з прогнозуванням опадів, зміною температури, напряму вітру тощо. У залежності від сезону характер спостережень за погодними явищами варіюється. Взимку основну увагу звертали на можливість відлиги, снігопаду, метелиці; влітку ж остерігалися грози, граду, засухи.

Аналізуючи короткотермінові метеорологічні передбачення жителів Полісся, звернемося до прикмет, які прогнозують літні опади. Дощ, як одне з найбільш яскравих погодних явищ, надзвичайно активно впливав на різноманітні сторони життя селянина, і спробам 
передбачити його наближення надавалося великого значення. Адже від гарних дощів одразу після засівання, в період проростання та росту хлібів аж до часу їх цвітіння і дозрівання залежало дуже багато.

Як свідчать прикмети, увага зверталася на різноманітні явища: на стан атмосфери, гігроскопічність предметів, зміни в житті флори та фауни, самопочуття людини. Калі сонще на заходе садзіщиа у тучу, то завтра дождж будзе (с. Корма, Добруський р-н, Гомельська обл. $)^{10}$. Венции большінство на мнєсящи - такіє кругі. Як иіє кругі є, то на дош (смт Чоповичі, Малинський р-н, Житомирська обл.) ${ }^{11}$. Звёзды вельмі блішать - к марозу (с. Ольшани, Столінський р-н, Брестська обл.) ${ }^{12}$. Як держиться роса, то не буде дошу. Як нема роси, то треба, шоб дош пошов (с. Пісківка, Бородянський р-н, Київська обл. $)^{13}$. Так дощ буде, якшо таке пір'я по небу. Як пір'я багато по небу, то дощ буде. Пірід домами вельми пір'я багато (с. Люб'язь, Любешівський р-н, Волинська обл.) ${ }^{14}$. Як соль одсирває, то погода буде сира (с. Колки, Дубровицький р-н, Рівненська обл.) ${ }^{15}$. Кури, як чуствують, шо непогода буде, у кучу збиваютия і щупаютия дуже (смт Димер, Вишгородський p-н, Київська обл.) ${ }^{16}$. Варонь каркають - к дажджу (с. Запрудівка, Добруський р-н, Гомельська обл. ${ }^{17}$. Будзе непагода, калі сабака уввесь дзень сонны (с. Скепня, Жлобінський p-н, Гомельська обл. $)^{18}$. Млявій конь робітия перед дощем, на погоду на сиру (с. Товстий Ліс, Чорнобильський р-н, Київська обл.) ${ }^{19}$. Бджоли як жужжать крепко, до то на вітер, на дощ (с. Заньки, Радомишльський р-н, Житомирська обл.) ${ }^{20}$. Голова в мене болить, ноги болять - на дощ. Спать хочетия тоже на дощ (с. Лемеші, Козелецький р-н, Чернігівська обл. $)^{21}$. Цей перелік можна було б продовжити, але й зазначених прикладів цілком достатньо для порівняння та аналізу.

Сучасне наукове метеопрогнозування, яке побудоване на інструментальних спостереженнях, позитивно оцінює деякі народні метеорологічні прикмети. Проте співставлення короткотермінових народних метеорологічних прикмет 3 даними сучасної метеорології виявляє і специфічні особливості народної метеорології. Наприклад, відсутність точного кількісного опису того чи іншого явища (нечітко виражений ступінь вологості солі, тютюну, колір неба, форма хмар та ін.). Такі особливості, як і недостатність окремих поодиноких спостережень (одна лише волога сіль не може слугувати $100 \%$ гарантією того, що скоро піде дощ), об'єктивно обумовлюють необхідність використання якомога більшої кількості неінструментальних спостережень для передбачення погоди.

Довгострокові передбачення погоди у поліщуків також грунтувалися на спостереженнях за широким колом даних - окремими метеорологічними явищами: життям природи. В основі його лежав сонячний цикл. У народному календарі $€$ дні та дати, котрі мають певний взаємозв'язок з особливими сезонними явищами, - це приказки-прикмети, які констатують, що в певні дні чи періоди року зазвичай буває певна погода. Хоч у XX ст. відбулися зміни у календарі, які спричинили до паралельного існування офіційного та народно-церковного календарів, деякі метеорологічні приказки продовжують побутувати в поліських селах. Трещи, не трещи, а пройшли Водохрещи (с. Сімаківка, Ємільчинський p-н, Житомирська обл.) $)^{22}$. Громныцы - половэна зылмыцы (с. Лелікове, Кобринський р-н, Брестська обл. $)^{23}$. Вербич - кожуха настербич (с. Дольськ, Любешівський р-н, Волинська обл.) ${ }^{24}$. Да Духа нє скідай кожуха (с. Кам'янська Слобода, Новгород-Сіверський p-н, Чернігівська обл.) $)^{25}$. Петро минає, палавину літа немає (с. Великий Карашин, Макарівський р-н, Київська обл.) ${ }^{26}$. Ілья наробіть гнілля (с. Хотомель, Столінський р-н, Брестська обл. $)^{27}$. Прайшов Спас - бері рукавіции празапас (с. Красне, Чернігівський p-н, Чернігівська обл.). ${ }^{28}$. Пакройкі - заганяй у хлеў кароўкі (с. Гуличі, Ляховицький p-н, Брестська обл $)^{29}$. Варвара заваріт, Сава засавіт, а Мікола закує і гвоздіком пріб'є (с. Немовичі, Сарненський р-н, Рівненська обл.) ${ }^{30}$.

Намагаючись передбачити примхи непостійної погоди, люди спостерігали за погодою окремих днів. Наприклад, весну прогнозували за погодою на Стрітення (15 лютого): Як на Стреченнє нап'єтйа пєвень води, то до Юр'я напасетияа вол трави (с Удрицьк, Дубровицький р-н, Рівненська обл.) $)^{31}$. На Стрэчанье як певень вады напь'етциа, то на Юръя вол напасещца (с. Матрунки, Мозирський р-н, Гомельська обл.) $)^{32}$; осінню погоду - за опадами на Мокрини (1 серпня): Як на Мокрину йде дощ, до обєда, до буде осень мокра, а як не буде дощу, то буде суха (с. Любарка, Народицький р-н, Житомирська обл.) ${ }^{33}$; погоду зими визначали за допомогою вітру на Покрову (14 жовтня): На Покрову дівілісь з якоє 
старани вєтєр - з тьопає чі з халоднає, шоб на зіму узнать (с. Вороб'їв, Ріпкинський р-н, Чернігівська обл. $)^{34}$.

Початок травня важлива пора у народному сільськогосподарському календарі українського поліщука. Тут дійсно кожен день рік годує, тому й багата ця пора на прикмети, які пов'язані з прогнозуванням майбутнього урожаю: Калі на Юр'я не было pacbl, дык год будзе галодны (с. Антонівка, Добруський р-н, Гомельська обл.) ${ }^{35}$. Як на Юрія жито в колосі, то на Петра буде в копах (с. Мелені, Коростенський р-н, Житомирська обл.) $)^{36}$. Калі варона на Юр’е будзе хаващиа ўжыце, то жыта добра ўродзіщь (с. Синичине, БудаКошельовський р-н, Гомельська обл. $)^{37}$. Як будє на Міколу колас, то будє у карови голас (с. Левковичі, Овруцький р-н, Житомирська обл. $)^{38}$.

Багато передбачень безпосередньо не були пов'язані з календарними датами. Так, після теплої зими очікували прохолодного літа. Для зручності запам'ятовування жителі краю послуговувалися приказками: Як зимою не змерз, то літом не нагрієшся (с. Івановичі, Пулинський р-н, Житомирська обл.) ${ }^{39}$. Калі зімой цёпла - летам холадна (с. Велетин, Хойницький p-н, Гомельська обл. $)^{40}$. Поліщуки, прагнучи дізнатися про погоду на тривалий період, спостерігали за рослинами та тваринами. Підгрунтям такого прогнозу $\epsilon$ багатовікові спостереження людей за природними явищами, неодноразово перевірені на практиці. Як люшина [вільха] вперед розов'єтия, то буде мокре лєто, а як береза - то буде сухе (с. Кисоричі, Рокитнівський р-н, Рівненська обл.) ${ }^{41}$. Глядзящь, што распустічиза раней, альха ичі бяроза. Калі альха, лета буде гнілое, калі бяроза - лета будзе сухое, иёплае (с. Синичине, Буда-Кошельовський р-н, Гомельська обл.) ${ }^{42}$. Багата ветак етых на рабіне, дак буде зіма халодная. А еслі вот мала ягад рабіны, дык значыць будзе цёплая зіма (м. Мозир, Гомельська обл. $)^{43}$. Як миши кубло високо кладут, то на велику зиму - холодно буде і снєгу багато. А якщо в земле кубла, то мала зима буде - тепла (с. Барвінки, Малинський р-н, Житомирська обл. $)^{44}$. Гусі леиящь нізко - зіма блізко, а высоко - далёко (с. Ольшани, Столінський р-н, Брестська обл. $)^{45}$. Віддавна українці Полісся, прагнучи передбачити, чи суворою буде зима, спостерігали за густотою чи довжиною хутра, пір'я тощо. Вважали, що тварини, передчуваючи холодну зиму, вирощують пухнастіше й тепліше хутро, аби краще протистояти зимовим холодам. Кури рано линяють на холодну зиму (с. Кам'янка, Березнівський р-н, Рівненська обл.) ${ }^{46}$. Проте останнім часом помітна переоцінка таких прикмет. Нині поліщуки вважають, що раніше линяють ті кури, які вже винеслися, тобто знесли всі заплановані на рік яйця.

У поліщуків й зараз зберігається чимало метеорологічних прикмет і ворожінь про погоду, урожай за кількістю снігу, інею в певні дні та періоди зимового циклу свят, зокрема напередодні та після Різдвяних святок. За уявленнями українців, усьому свій час і своя пора. Так, узимку має бути холодно та сніжно, а влітку - тепло та волого. Як сніг на полі, то хліб на столі (с. Залізниця, Любешівський р-н, Волинська обл. $)^{47}$. Рясний іній прогнозував урожай зернових, за його наявністю визначали врожай окремих культур, зокрема садовини. Як інєй, до кажуть, шо багатий буде год (с. Потаповичі, Овруцький р-н, Житомирська обл. $)^{48}$. Як іней $\epsilon$, то на врожсай фрукти (с. Пісківка, Бородянський р-н, Київська обл. $)^{49}$. На Піліпаўку іней - авёс добры будзе (с. Крупейки, Лоэвський р-н, Гомельська обл. ${ }^{50}$. Подекуди на Поліссі для передбачення врожаю спостерігали за бурульками. Якшо зімою розтає $i$ багато ото сосулок. Вони щитаютия, як дерево коренем уверх. Якшо їх багато: великиє, маленькиє, всякиє - буде гарний урожсай на все (с. Феневичі, Іванківський р-н, Київська обл. $)^{51}$. Еслі на крышах сасулькі вісящь, будзе малочны год (с. Задуб'я, Кормянський р-н, Гомельська обл. $)^{52}$. На відміну від інею та бурульок сніг дійсно відіграє значну роль для майбутнього врожаю: 1) він, покриваючи землю, охороняє посіви від вимерзання; 2) збагачує грунти поживними речовинами, які разом із зимовими опадами потрапляють в землю при таненні снігу навесні; 3) сніг збагачує грунти необхідною вологою ${ }^{53}$.

Тісно пов'язані з кількістю снігу взимку кількість опадів весною та влітку, а відповідно й погодні умови, сприятливі для вирощування врожаю. Вогкий і дощовий рік $є$ для жителів Полісся урожайним роком, то ж і не дивно, що вони прогнозують таким чином урожай зернових та грибів за кількістю зірок. Практично по всьому регіону побутує прикмета: Калі на Каляды ноччу шмат зорак у небе, то ўлетку ждзі багаты год на грыбы (с. Рафалів, Брагінський р-н, Гомельська обл.) ${ }^{54}$. У с. Мелені Коростенського р-ну Житомирської обл. інформатори уточнюють, що зорі на кожну Кутю Різдвяних святців ві- 
щують відповідні врожаї грибів наступного року, тобто таким чином можна й передбачити опади в певні періоди року: як на Першу кутю багато зорок, то будуть рости микольніє грібі (кінець травня - початок червня), як на багату Кутю багато зорок, то вродить багато грібов лєтом, а як на Голодну багато зорок, то будуть позніє грібі ${ }^{55}$.

Важливого значення надавалося на Поліссі першому грому, який вважався подією вагомою і супроводжувався різноманітними ритуалами, які мали, за народною уявою, забезпечити добробут людей протягом наступного господарчого року. Серед таких ритуалів найбільш розповсюджені: притулитися спиною до дерева, перекотитися по землі, умитися чи облитися водою тощо. Проте перший грім пов'язували також і 3 прогнозуванням урожаю протягом наступного року. Калі першы гром на голь лес, няма яшчэ льсиеу на дрэвах, то будзе гнілое лета, з дажджом, буде холадна, нічога не вырасие (с. Синичине, Буда-Кошельовський р-н, Гомельська обл. $)^{56}$. Як перший раз загриміло на голе дерево, то неврожай буде, голодовка (смт Красятичі, Поліський р-н, Київська обл.) ${ }^{57}$. В останні роки грім буває досить раннім, тобто вперше гримить, коли дерева ще не розпустилися, але жителі Полісся зазначають, що голоду немає, хоч урожай значно менший на різноманітні сільськогосподарські культури.

На Поліссі досі знаними є дні та деякі періоди року, коли заборонялося працювати 3 метою уникнення несприятливих явищ погоди. Значне місце тут посідають громові та градові дні, яким притаманні різноманітні ознаки на теренах краю. Лля - перше громове свято, нє Лля - друге. Гаврилей - перше, а Паликопа - третє. Паликопа - ие Пантєлєй (с. Романівка, Новоград-Волинський р-н, Житомирська обл. $)^{58}$. Палікопа - Пантєлєймон - нечого не робілі, шоб не спалів гром (с. Хочине, Олевський р-н, Житомирська обл.) $)^{59}$. Іноді такі дні не припадають на якісь числа, а прикріплені до якогось важливого великого свята, зокрема Великодня чи Трійці. У білорусів такі свята прийнято називати варавітылі, тобто особливо небезпечними. Вот ёсть варавітыя празнікі - Барыс, Чуда (с. Шалипи, Калинковицький р-н, Гомельська обл.) ${ }^{60}$. Майже всі зазначені дні не залучені до переліку так званих приписних святкових днів, проте їх святкують селяни зі звичайної забобонності. Майже в кожному населеному пункті ми чули оповідки про роботи в громові дні та про покарання, які спіткали працюючих. Колись осьо у нас через дорогу люде поєхали косить на Паликопу. До гром усє їхніє копи спалив. Тепер не йдуть. Нечого не можна робить у полі: не косить, не в'язать, не складать (с. Поліське, Коростенський р-н, Житомирська обл. ${ }^{61}$. Поліщуки були переконані, що ці дії відбувалися в їхньому населеному пункті й називали прізвища людей, які зазнали такого лиха.

Поряд з науковими метеорологічними передбаченнями на Середньому Поліссі до кінця XX ст. збереглася певна кількість магічних оберегових засобів впливу на погоду, хоча й спостерігається їхнє скорочення та спрощення. Це можна пояснити освіченістю навіть людей старшого віку, більшість з яких навчалася у школах, отримувала інформацію з радіо та телебачення.

Досі вагоме місце у агрометеорологічних віруваннях українців Полісся, пов'язаних 3 народним календарем, займає Благовіщення та час, котий передує йому. Да Благавешчання не паложана чапацьь зямлю, пахащь там, капаць, асобенна гарадзіџь заборы, таго што летам будзе бальшая засуха: забор будзеш гарадзіџь $і$ дождж загародзіш (с. Кривськ, Буда-Кошельовський р-н, Гомельська обл.) ${ }^{62}$. Інформатори зазначають, що зараз вони починають обробляти землю раніше поки вона ще достатньо насичена вологою. Інколи вони вказують, що не дотримуються заборон доторкатися до землі та городити до Благовіщення, оскільки у південних районах України та в інших державах починають працювати у полі, не чекаючи Благовіщення. Значну роль у процесі знищення цього вірування відіграє православна церква, священики якої продовжують викорінювати поганські традиції українців-поліщуків. Батюшка сказав, шо могелкі треба загородить до Благовєщення. Тепер і гріміть, $i$ хмарі ходять, а у нас дощу нема. Треба було б розобрать забора, але хто ж пойде розгорожувать могелкі (с. Мелені, Коростенський р-н, Житомирська обл. $)^{63}$.

Від розвинутих обрядодій викликання дощу, головним елементом яких були ритуальні обходи селом 3 магічно «сильними» предметами: іконами, корогвами, релігійними книгами та ін. Шоб дощ пішов піп ходив, молилися, співали біля річки, просили дощу (с. Романівка, Новоград-Волинський р-н, Житомирська обл. $)^{64}$. Як не було дощу, до йшли 
до живоє кринички, молилися Богу. 3 корогвами ішли, з усєм (с. Поліське, Коростенський p-н, Житомирська обл. ${ }^{65}$. Дождж вызылвалі, як служыв баџуюшко в иееккві. Выходзів батюшко з иерквы, берут людзі корогві і ідзём по полях. Каждое поле обходзім. Все ідут - $i$ малые, $i$ большіе - $i$ певні поют. I так ходзім, пока все полі не обойдзем. А як домой возврашчаліся, то дождж як з ведра ішов (с. Варані, Столінський р-н, Брестська обл.) ${ }^{66}$.

3 метою припинення дощу поліщуки і нині послуговуються християнськими символами - предметами, освяченими у церкві (верба, освячена у Вербну неділю, хрещенські ялинкові галузки, троїцьке клечання, стрітенська та страсна свічки тощо). Вербу святу кідалі у пєч, шоб гром не спалив хату (с. Залісся, Чорнобильський р-н, Київська обл.) ${ }^{67}$. Як гроза, до палили ту сосну, шо ставіциа, як воду сьватять. Люде ламали, брали додому i палили. Палили под коменом, на пріпеку (смт Чоповичі, Малинський р-н, Житомирська обл.) ${ }^{68}$. Паньку [троїцьке клечання - О. В.] палять у печи, шоб не було пожару (с. Хочине, Олевський р-н, Житомирська обл. ${ }^{69}$. На вакно ставілі свянцоныя кляновыя дубиы, каб маланку не прыцягваць (с. Лучици, Петриковський р-н, Гомельська обл. ${ }^{70}$. Свічку-громовицю [стрічальну свічку - О. В.] світять, коли грім. Ходять з нею по хаті, по вуглах, обходять кругом хати і світять у хаті, шоб гром одійшов (с. Мироцьке, Києво-Святошинський p-н, Київська обл. $)^{71}$. Запальвалі тако ж свечку стречную. Она оберегала от удара молніі (с. Варані, Столінський р-н, Брестська обл. $)^{72}$.

Нині з метою припинення грози та граду практично не використовується пічне начиння (рогач, кочерга, пікна лопата), які у більшості випадків вийшли з ужитку. В окремих населених пунктах пічне опалення замінено газовим, відійшло у минуле випікання хліба вдома. Навіть там, де ще зберігаються ці предмети хатнього вжитку, їх перестали використовувати, оскільки втрачено магічні вірування причинно-наслідкових зв'язків між вогнем та грозою.

Так само відійшли у минуле чарівники-ворожбити, які уміли розганяти грозові хмари. Якщо місцеві жителі практично повсюдно використовували різноманітні предмети для впливу на атмосферні явища: хлібну лопату та інші предмети пічного начиння, освячену вербу, громову свічку тощо, то люди, наділені езотеричними здібностями, не користуються ніякими предметами. Досить часто інформатори вказують, що вони були знайомі 3 такими людьми, які могли відвести хмару, але, що ті робили та яким чином, вони розповісти не могли. Наша сусєдка, як мав іти дощ з громом, віходила з іконою з дому. Віде да помолитиа, така ікона є Божа. Пойде хмара і дощу не буде, $і$ грому. Ізжене (с. Йосипівка, Малинський $\mathrm{p}-\mathrm{H}$, Житомирська обл. $)^{73}$. Цілком закономірним $є$ факт, що респонденти набагато менше дають свідчень про хмарників, адже у радянські часи влада вела нищівну боротьбу зі всякими забобонами.

Серед поліщуків побутували уявлення про те, що «нечисті» покійники, частіше вішальники та утопленики, поховані на кладовищі, тобто у «чистому» місці, можуть накликати засуху, неврожай, епідемії, стихійні лиха тощо. Як є такі мертві, шо повєсітиа, то дощу нє будє (с. Колки, Дубровицький р-н, Рівненська обл. $)^{74}$. Їх хоронили поза межами кладовища, у місцях віддалених від людей, найчастіше, - на роздоріжжі. Вєшалников не ховали у кладбищі, а на розходніх дорогах і хрестов не ставіли (с. Старий Дорогинь, Народицький p-н, Житомирська обл. $)^{75}$. Помітна тенденція зменшення впливу цієї традиції, яка проявляється у ставленні односельчан до покійника-самогубці. Оскільки у поліських селах прийнято хоронити покійників біля родичів, то це призводить до того, що вони потрапляють поміж звичайними мерцями. Родичі померлих виготовляють фіктивні довідки про те, що ті хворіли та добиваються дозволу від єпископів на здійснення поховань зі священиком. Вєшальников колісь везлі на гранииу, а тепер на кладбища, ще й у иерков несуть (с. Немовичі, Сарненський р-н, Рівненська обл. ${ }^{76}$.

Причиною засухи може бути сплюндрована земля кладовища, тому потрібно було пошкодити могилу нечистого покійника - нейтралізувати надприродні сили. Якщо у минулому це було руйнування могили, то зараз це виривання хреста. Я вот знаю, шо як павесіуся чалавек, і дашчу няма. Так калісь хадзілі і красты выварачывалі із пакойніка, на кладбіщы. Выварачывалі этия красты, шоб пашой дошч (с. Корма, Добруський р-н, Гомельська обл.) ${ }^{77}$. Поліщуки пояснюють це тим, що покійник-самогубець не може мати християнського символу, бо продався нечистому. У народній пам'яті зберігаються вірування про оберегові властивості осики, яка рятує людину від чортівні та відьом. Якщо 
наприкінці XIX ст., щоб до живих не ходив покійник, у його могилу вбивали кілка, для гробу відьми чи упиря виготовляти кришку з осикових дощок тощо ${ }^{78}$, то через 100 років у с. Колки Дубровицького р-ну Рівненщини, щоб мрець не виходив до живих, у труну всім померлим забивають осикового кілочка ${ }^{79}$.

До початку XXI ст. з метою викликання дощу збереглося «жертвоприношення» водам, яке притаманне жителям населених пунктів по усьому регіону. Проте з усього різноманіття предметів, які кидали у криницю (мак-видюк, зерна льону, жито, пшениця, горох, капуста, часник, цибуля, сіль, борщ, хліб, квіти, гроші, цілі та розбиті горщики, спеціально виготовлений хрест, освячена вода ${ }^{80}$, залишилося переважно лише сипання маку-видюку. Як дожджу нэма, то ранэнько, до уцсходу сониа у 9 колодэзыв сыплюиь зэрно, мак свэнчоны у иееккві (с. Войтешин, Березівський р-н, Брестська обл.) ${ }^{81}$. Сакральне значення останнього на Поліссі настільки суттєве, що він зумів перебрати на себе ритуальну функцію всіх інших названих вище речей. Пару год назад троє сусєдніх дівчаток кідали чілиє сьвачениє маковкі в криници. 9 маковок треба укинуть у 9 криниц. Вони кідали і казали ще щцось про Бога. Але я не помню. Я ̈̈м щее пообещала, шо дам по рублю, як дощ пойде. Да. Пошов. Заробіли девочкі (с. Мелені, Коростенський р-н, Житомирська обл.) $)^{82}$.

До середини XX ст. у поліських селах широко побутувало ткацтво - виготовлення рушників, скатертин, звичайного полотна. У регіоні, як своєрідна жертва, було широко розповсюджене виготовлення одноденного полотна, яке ткали у критичні моменти життя: бездощів'я, повальних хвороб, епідемій тощо. Не было дажджу дзелалі абудзённік. Адна прадзе, другая, і снующьь, і ткуиь. За адзін дзень губку наткуцьь. I тады ета палатно, была дарога крыжавая, вот примерна там укапывалі хрэст і вешалі. I штоб ішоў дождж. Om, Богу малілісь. От, эта я помню, было (с. Червоний Октябрь, Буда-Кошельовський p-н, Гомельська обл.) $)^{83}$. При виготовленні «обиденного» полотна поліщуки дотримувалися численних обмежень: час (протягом ночі), кількість (частіше дев'ять чи дванадцять) та ритуальна чистота учасниць (вдови, старі жінки) обряду. Таким чином, маємо приклад збереження традиційного мислення, згідно з яким виготовлений людиною новий предмет у особливих ритуальних умовах наділявся надприродними властивостями, а відтак здатності впливати на світ, налаштовувати правильний порядок розвитку.

Певною видозміною виготовлення «обиденного» полотна наприкінці XX ст. стала традиція пов'язати на хресті-фігурі речі, хоч і придбані у магазині, але також виготовлені способом ткання - хустки, рушники. Як ие довго нема дощу, збіраютиа люде, йдуть до иеркві, берут корогві, беруть рушникі да хусточкі, ио в кого є. Ідуть до хвігурі. Там в'яжуть, співають, батюшка правіть (смт Чоповичі, Малинський р-н, Житомирська обл. $)^{84}$. Поліщуки відмічають, що часто обрекаютца виготовити або придбати на церкву рушника, хустку, тканину у випадку тяжкої хвороби близької людини. Таким чином обиденні дії замінюються обітними для посилення молитовного прохання і як певна ритуальна гарантія його виконання ${ }^{85}$.

Суттєвих змін зазнали такі магічні дії для викликання дощу, як убивство жаби, вужа, рака, руйнування мурашників тощо. Традиція вірувань у здібності хтонічних тварин впливати на погоду практично перервана. Більше того, поліщуки й пояснюють це раціонально: недоцільно завдавати шкоди живим організмам, вони невинні у бездощів ї і не можуть нічим допомогти людям.

Короткотермінові прикмети на території Українського та Білоруського Полісся характеризуються певною однорідністю з деякими незначними відмінностями в певних районах, що обумовлено природно-кліматичними умовами. Сучасні свідчення й ті матеріали, які були записані наприкінці XIX - на початку XX ст., практично ідентичні, що свідчить про стійкість знань у народній пам'яті. Певне зменшення сучасного етнопрогнозування можна пояснити тим, що на перший план вийшли наукові методи передбачення погоди. Проте перевірені часом прикмети, продовжують побутувати у поліських селах і зараз. Довгострокові метеорологічні прогнози, пов'язані з народним календарем, ще зберігає пам'ять людей старшого віку. Зважаючи на значне потепління останніх років, поліщуки відмічають, що сезонно-повторювані явища починають втрачати взаємозв'язки між собою. Як свідчать сучасні матеріали, народна пам'ять на Поліссі й досі зберігає чимало давніх архаїчних форм і елементів духовної культури, пов'язаних з метеорологічною тематикою - методи корегування погодних явищ: засухи, зливи, грози, граду. 
${ }^{1}$ Василенко В. И. Метеорология и земледелие по украинским народным воззрениям с программой для собирания материалов. Полтава, 1902. 91 с.; Гринченко Б. Д. Этнографичские материалы, собранные в Черниговской и соседних с ней губерниях. Чернигов, 1895. Вып. І. 308 с.; Кравченко В. Звичаї у селі Забрідді та по деяких інших, недалеких від цього села місцевостях Житомирського повіту на Волині: Етнографічні матеріали, зібрані Кравченком Васильом. Житомир, 1920. 244 с.; Кравченко В. Этнографические материалы, собранные В. Гр. Кравченко на Волыни и в соседних с ней губерниях // Труды Общества исследователей Волыни. Житомир, 1911. Т. 5. С. 88-148; Максимович М. А. Собрание сочинений. К., 1877. Т. II. VIII+524 с., 2 табл.; Труды этнографостатистической экспедиции в Западно-Русский край, снаряженной Императорским русским географическим обществом. Юго-Западный отдел. Материалы и исследования, собранные д. чл. П. П. Чубинским. СПб., 1872. Т. І. ХХХ +224 с.

${ }^{2}$ Никифоровский Н. Я. Простонародные приметы и поверья, суеверные обряды и обычаи, легендарные сказания о лицах и местах. Витебск, 1877. 307 с.; Сержпутоўскі А. Прымхі і забабоны беларусаў-паляшукоў. Менск, 1930. 284 с.

${ }^{3}$ Машынскі К. Усходняе Палессе. Мінск, 2014. 528 с.; Сержпутоўскі А. К. Русальная нядзеля. Прымхі і забабоны беларусаў-паляшукоў. Мінск, 2009. 478 с.

${ }^{4}$ Болтарович 3. Е., Минько Л. И., Мороз Я. А., Федорив О. Р. Народные знания // Общественный, семейный быт и духовная культура населения Полесья. Минск: Наука и техника, 1987. С. 184-232.

${ }^{5}$ Федорів О. Із народної метеорології поліщуків // Жовтень. 1984. № 5. С. 99-104; Федорів О. Р. Народна метеорологія українців Полісся // Народна творчість та етнографія. 1984. № 6. С. $52-55$.

${ }^{6}$ Толстая C. М. Лягушка, уж и другие животные в обрядах вызывания и остановки дождя // Славянский и балканский фольклор. Духовная культура Полесья на общеславянском фоне. М.: Наука, 1986. С. 22-27; Толстая С. М. Пахание реки, дороги // Славянский и балканский фольклор. Духовная культура Полесья на общеславянском фоне. М.: Наука, 1986. С. 18-22; Толстая C. М. Стретенская и четверговая свечи // Славянский и балканский фольклор. Духовная культура Полесья на общеславянском фоне. М.: Наука, 1986. С. 27-30; Tолстые Н. И. и С. М. Заметки по славянскому язычеству. 1. Вызывание дождя у колодца // Русский фольклор. Ленинград: Наука, 1981. Т. 21. С. 87-98; Tолстые Н. И. и С. М. Заметки по славянскому язычеству. 2. Вызывание дождя в Полесье // Славянский и балканский фольклор. Генезис, архаика, традиции. М.: Наука, 1978. С. 95-130; Толстыле Н. И. и С. М. Заметки по славянскому язычеству. 3. Первый гром в Полесье. 4. Защита от града в Полесье // Обряды и обрядовый фольклор. М.: Наука, 1982. С. 49-83; Толстыле Н. И. и С. М. Заметки по славянскому язычеству. 5. Защита от града в Драгачеве и других сербских зонах // Славянский и балканский фольклор. Обряд. Текст. М.: Наука, 1981. С. 44-120.

${ }^{7}$ Агапкина T. A. Мифологические основы славянского народного календаря. Весенне-летний цикл. М.: Наука, 2002. 816 с.; Виноградова Л. Н. Народная демонология и мифо-ритуальная традиция славян. М.: Индрик, 2000. 432 с.; Гура A. В. Символика животных в славянской народной традиции. М.: Индрик, 1997. 912 с.; Гура А. В. Брак и свадьба в славянской народной культуре: Семантика и символика. М.: Индрик, 2012. 936 с.; Журавлев А. Ф. Домашний скот в поверьях и магии восточных славян. Этнографические и этнолингвистические очерки. М.: Индрик, 1994. 256 с.; Полесские заговоры (в записях 1970-1990 гг.) / Сост., подготовка текстов и коммент. Т. А. Агапкиной, Е. Е. Левкиевской, А. Л. Топоркова. М.: Индрик, 2003. 752 с.; Толстая С. М. Полесский народный календарь. М.: Индрик, 2005. 600 с.; Толстой Н. И. Очерки славянского язычества. М.: Индрик, 2003. 624 с.; Левкиевская E. E. Славянский оберег. Семантика и структура. М.: Индрик, 2002. 336 с.; Народная демонология Полесья: Публикации текстов в записях 80-90-х годов XX века. Т. 1: Люди со сверхестественными свойствами / Сост. Л. Н. Виноградова, Е. Е. Левкиевская. М., 2010. 648 с.; Народная демонология Полесья: Публикации текстов в записях 80-90-х годов XX века. Т. 2: Демонологизация умерших людей / Сост. Л. Н. Виноградова, Е. Е. Левкиевская. М., 2012. 800 с.; Народная демонология Полесья. Публикации текстов в записях 80-90-х гг. XX века. T. 3: Мифологизация природных явлений и человеческих состояний / Ред.-сост. Л. Виноградова, Е. Левкиевская. М.: Издательский дом ЯСК, 2016. 832 с.

8 Васянович О. «Нечисті» покійники в метеорологічних уявленнях жителів Центральноукраїнського Полісся // Народознавчі зошити. 2006. № 3-4. С. 398-402; Васянович О. Вогонь як засіб боротьби зі зливою та градом на Поліссі // Поліссєзнавство: наукові фольклорно-етнографічні та мистецтвознавчі студії. Рівне, 2006. С. 211-216; Васянович О. Загальна та регіональна характеристика короткотермінових метеорологічних знань українців Середнього Полісся // Вісник Львівського університету. Серія історична. Львів, 2008. Вип. 43. С. 421-451; Васянович О. Магічні засоби попередження несприятливих явищ погоди на Коростенщині // Наукові записки. Івано-Франківськ, 2003. Вип. 7-8. С. 110-114; Васянович О. Метеорологічні вірування, пов'язані з аграрним календарем (за матеріалами Центральноукраїнського Полісся) // Матеріали до української етнології. К., 2007. С. 36-41; Васянович О. Метеорологічні знання та вірування українців-поліщуків, пов'язані 3 днем Благовіщення // Західне Полісся: історія та культура. Рівне, 2006. Вип. 2. С. 211-216; Васянович О. Метеорологічні прикмети в народному календарі українців Полісся // Народна творчість та етнографія. 2005. № 2. С. 86-92; Васянович О. Народні метеорологічні знання поліщуків // Берегиня. 2005. 
№ 2. С. 53-64; Васянович О. Раціоналізм окремих народних метеопрогнозів жителів Середнього Полісся // Минуле і сучасне Волині й Полісся: роде наш красний. Луцьк, 2007. Вип. 24. С. 258261; Васянович O. Своєрідність народних агрометеорологічних знань на Поліссі // Матеріали до української етнології. Збірник наукових праць. К., 2004. Вип. 4 (7). С. 22-25; Васянович О. О. Метеорологічні знання та вірування українців на території, постраждалій від Чорнобильської катастрофи // Чарнобылем не зарасце: традыцыі матэрыяльнай і духоўнай культуры Усходняга Палесся: зборнік навуковых артыкулаў: у 2 ч. Гомель: ГДУ імя Ф. Скарыны, 2016. Ч. 1. С. 83-91.

9 Чибирак $C$. Грім та гроза у світогляді мешканців Ратнівщини // Минуле і сучасне Волині та Полісся. Ратнівщина в історії України та Волині. Науковий збірник. Луцьк, 2012. Вип. 42. С. 311312; Чибирак C. Гроза у народних знаннях і віруваннях поліщуків // Минуле і сучасне Волині та Полісся. Сереховичі в історії України, Волині та Полісся. Наук. зб. Луцьк, 2006. Вип. 21. С. 5658; Чибирак $C$. Збереження народних знань та світоглядних уявлень мешканцями Житомирського Полісся // Науковий вісник Східноєвропейського національного університету імені Лесі Українки. Серія: Історичні науки. 2013. № 21 (269). С. 177-182; Чибирак С. Магічні дії, спрямовані на захист від грози і викликання дощу, в традиційній культурі Полісся // Минуле і сучасне Волині та Полісся. Камінь-Каширський в історії Волині та України. Наук. зб. Луцьк, 2006. Вип. 20. С. 207-210; Чибирак C. Народні знання Волинського Полісся (за матеріалами експедиції до Ратнівського району Волинської області) // VII Кирилло-Мефодиевские чтения в 2-х частях // Материалы Международной научно-практической конференции. Уфа, 2014. Ч. 1. С. 73-78; Чибирак С. Народні знання і світоглядні уявлення поліщуків як відображення колективного досвіду (за матеріалами Коростенського, Лугинського і Овруцького районів Житомирської області) // Минуле і сучасне Волині та Полісся: Роде наш красний. Луцьк, 2007. С. 84-86; Чибирак С. Прогнозування дощу на Житомирському Поліссі // Минуле і сучасне Волині та Полісся. Сторінки воєнної історії Маневиччини та Полісся. Наук. зб. Луцьк, 2006. Вип. 19. С. 61-64.

10 Прыкметы і павер'і Гомельшчыны / Укладанне, сістэматызацыя, тэксталагычная праца, уступныя артыкулы В. С. Новак, А. А. Кастрыца. Гомель, 2007. С. 196.

11 Запис автора 1 липня 2003 р. у смт Чоповичі Малинського р-ну Житомирської обл. від Старченко Н. В., 1935 р. н.

12 Жыццё і побыт беларусаў у прыкметах і павер'ях / Аўтары-ўкладныкы: В. С. Новак, А. А. Кастрыца, К. В. Паборцава; Гомельскі дзяржаўны ўніверсітэт імя Ф. Скарыны. Мінск: Права і эканоміка, 2014. С. 119.

13 Запис автора 5 липня 2003 р. у с. Пісківка Бородянського р-ну Київської обл. від Панчик Павлини Іванівни, 1914 р. н.

14 Запис автора 30 липня 2015 р. у с. Люб'язь Любешівського р-ну Волинської обл. від Іванісік Марії Сидорівни, 1930 р. н.

15 Запис автора 8 жовтня 2004 р. у с. Колки Дубровицького р-ну Рівненської обл. від Кутяш Серафими Федорівни, 1923 р. н.

16 Запис 15 серпня 2003 р. у смт Димер Вишгородського р-ну Київської обл. від Куценко Галини Оникіївни, 1924 р. н.

17 Прыкметы і павер’і Гомельшчыны / Укладанне, сістэматызацыя, тэксталагычная праца, уступныя артыкулы В. С. Новак, А. А. Кастрыца. Гомель, 2007. С. 195.

${ }^{18}$ Народная міфалогія Гомельшчыны: фальклорна-этнаграфічны зборнік. Мінск, 2003. С. 270.

19 Запис автора 25 вересня 2003 р. у с. Липівка Макарівського р-ну Київської обл. від Глюзи Олексія Івановича, 1926 р. н., переселенця з с. Товстий Ліс Чорнобильського р-ну.

20 Запис автора 18 червня 2004 р. у с. Заньки Радомишльського р-ну Житомирської обл. від Барвінської Олександри Вікторівни, 1928 р. н.

21 Запис автора 20 вересня 2003 р. у с. Лемеші Козелецького р-ну Чернігівської обл. від Лазаренко Ганни Кирилівни, 1925 р. н.

22 Запис автора 19 листопада 2006 р. у с. Сімаківка Смільчинського р-ну Житомирської обл. від Солоб Надії Архипівни, 1926 р. н. та Савуха Леоніда Андрійовича, 1926 р. н.

23 Традыцыйная мастацкая культура беларусаў. У 6 т. Т. 4. Брэсцкае Палессе. У 2 кн. Кн. $2 /$

А. М. Боганева [і інш.]. Мінск, 2009. С. 607.

24 Запис автора 26 липня 2015 р. у с. Дольськ Любешівського р-ну Волинської обл. від Сороки Надії Дмитрівни, 1932 р. н.

25 Запис автора 17 вересня 2009 р. у с. Кам'янська Слобода Новгород-Сіверського р-ну Чернігівської обл. від Тихенько Анастасії Іванівни, 1932 р. н.

26 Запис автора 8 липня 2004 р. у с. Великий Карашин Макарівського р-ну Київської обл. від Аксьоненко Євдокії Яківни, 1920 р. н. та Свченко Софії Федотівни, 1925 р. н.

27 Жыццё і побыт беларусаў у прыкметах і павер'ях / Аўтары-ўкладныкы: В. С. Новак, А. А. Кастрыца, К. В. Паборцава; Гомельскі дзяржаўны ўніверсітэт імя Ф. Скарыны. Мінск: Права і эканоміка, 2014. С. 100.

28 Запис автора 20 вересня 2003 р. у с. Красне Чернігівського р-ну Чернігівської обл. від Легкобит Парасковії Протасівни, 1932 р. н. 
29 Традыцыйная мастацкая культура беларусаў. У 6 т. Т. 4. Брэсцкае Палессе. У 2 кн. Кн. 2 / А. М. Боганева [і інш.]. Мінск, 2009. С. 608.

30 Запис автора 9 жовтня 2004 р. у с. Немовичі Сарненського р-ну Рівненської обл. від Мички Олександри Михайлівни, 1926 р. н.

31 Запис автора 8 жовтня 2004 р. у с. Удрицьк Дубровицького р-ну Рівненської обл. від Пігель Єви Степанівни, 1923 р. н.

${ }^{32}$ Кухаронак Т. И. Календарные празники Мозырско-Припятского Полесья // Этнокультурные процессы Восточного Полесья в прошлом и настоящем. Минск, 2010. С. 328.

33 Запис автора 7 липня 2004 р. у с. Нові Озеряни Брусилівського р-ну Житомирськоїа обл. від Клімчук Любові Петрівни, 1927 р. н., переселенки з с. Любарка Народицького р-ну

34 Запис автора 13 вересня 2009 р. у с. Вороб’їв Ріпкинського р-ну Чернігівської обл. від Семеняки Євдокії Яківни, 1926 р. н. та Семенюк Уляни Пилипівни, 1935 р. н.

35 Прыкметы і павер'і Гомельшчыны / Укладанне, сістэматызацыя, тэксталагычная праца, уступныя артыкулы В. С. Новак, А. А. Кастрыца. Гомель, 2007. С. 211.

36 Запис автора 7 вересня 2011 р. в с. Мелені Коростенського р-ну Житомирської обл. від Васянович Людмили Іванівни, 1951 р. н.

${ }^{37}$ Народная міфалогія Гомельшчыны: фальклорна-этнаграфічны зборнік. Мінск, 2003. С. 284.

38 Запис автора 4 квітня 2004 р. у с. Левковичі Овруцького р-ну Житомирської обл. від Левковської Олександри Григорівна, 1921 р. н.

39 Запис автора 19 червня 2004 р. у с. Івановичі Пулинського р-ну Житомирської обл. від Степанчук Антоніни Михайлівни, 1927 р. н. та Степанчук Марії Сергіївни, 1956 р. н.

${ }^{40}$ Кастрица E. A. Метеорологические приметы и поверья белорусов в восточнославянском контексте // Мова і культура. К., 2012. Вип. 15. Т. І. С. 145.

41 Запис автора 13 серпня 2006 р. у с. Кисоричі Рокитнівського р-ну Рівненської обл. від Сича Федора Йосиповича, 1928 р. н.

${ }^{42}$ Народная міфалогія Гомельшчыны: фальклорна-этнаграфічны зборнік. Мінск, 2003. С. 275.

${ }^{43}$ Кастрица E. A. Метеорологические приметы и поверья белорусов в восточнославянском контексте // Мова і культура. К., 2012. Вип. 15. Т. І. С. 144.

44 Запис автора 1 липня 2003 р. у с. Барвінки Малинського р-ну Житомирської обл. від Шпакович Ольги Петрівни, 1928 р. н., Прокопенко Зінаїди Степанівни, 1956 р. н. та Мойсієнко Марії Степанівни, 1952 р. н.

45 Жыццё і побыт беларусаў у прыкметах і павер'ях / Аўтары-ўкладныкы: В. С. Новак, А. А. Кастрыца, К. В. Паборцава; Гомельскі дзяржаўны ўніверсітэт імя Ф. Скарыны. Мінск: Права і эканоміка, 2014. С. 120.

46 Запис автора 10 жовтня 2004 р. у с. Кам’янка Березнівського р-ну Рівненської обл. від Драганчук Слизавети Іванівни, 1910 р. н. та Базелюк Надії Миколаївни, 1953 р. н.

47 Запис автора 24 липня 2015 р. у с. Залізниця Любешівського р-ну Волинської обл. від Лащ Ганни Тимофіївни, 1936 р. н.

48 Запис автора 2 квітня 2004 р. у с. Потаповичі Овруцького р-ну Житомирської обл. від Медведчук Марії Іванівни, 1938 р. н., Медведчук Галини Ничипорівни, 1939 р. н., Гайденко Марії Карпівни, 1916 р. н. та Федчика Петра Олексійовича, 1950 р. н.

49 Запис автора 5 липня 2003 р. у с. Пісківка Бородянського р-ну Київської обл. від Харченко Антоніни Омелянівни, 1927 р. н., родом з с. Тетерівське Іванківського р-ну.

50 Жыццё і побыт беларусаў у прыкметах і павер'ях / Аўтары-ўкладныкы: В. С. Новак, А. А. Кастрыца, К. В. Паборцава; Гомельскі дзяржаўны ўніверсітэт імя Ф. Скарыны. Мінск: Права і эканоміка, 2014. С. 91.

51 Запис автора 14 серпня 2003 р. у с. Феневичі Іванківського р-ну Київської обл. від Харченко Марії Петрівни, 1921 р. н. та Настенко Марії Павлівни, 1923 р. н.

52 Прыкметы і павер'і Гомельшчыны / Укладанне, сістэматызацыя, тэксталагычная праца, уступныя артыкулы В. С. Новак, А. А. Кастрыца. Гомель, 2007. С. 92.

${ }_{53}$ Ермолов А. Народная сельскохозяйственная мудрость в пословицах, поговорках и приметах. СПб., 1905. Т. II. Всенародная агрономия. С. 348.

54 Прыкметы і павер'і Гомельшчыны / Укладанне, сістэматызацыя, тэксталагычная праца, уступныя артыкулы В. С. Новак, А. А. Кастрыца. Гомель, 2007. С. 90.

55 Запис автора 7 вересня 2011 р. в с. Мелені Коростенського р-ну Житомирської обл. від Васянович Людмили Іванівни, 1951 р. н.

${ }^{56}$ Народная міфалогія Гомельшчыны: фальклорна-этнаграфічны зборнік. Мінск, 2003. С. 299.

57 Запис автора 14 серпня 2003 р. у смт Красятичі Поліського р-ну Київської обл. від Аврамчук Катерини Григорівни, 1925 р. н.

58 Запис автора 1 жовтня 2004 р. у с. Романівка Новоград-Волинського р-ну Житомирської обл. від Сощук Ольги Калістратівни, 1926 р. н. та Сощука Василя Пархомовича, 1924 р. н.

59 Запис автора 26 серпня 2003 р. у с. Хочине Олевського р-ну Житомирської обл. від Шинкар Варвари Олександрівни, 1935 р. н. 
${ }^{60}$ Кухаронак Т. И. Календарные празники Мозырско-Припятского Полесья // Этнокультурные процессы Восточного Полесья в прошлом и настоящем. Минск, 2010. С. 338.

61 Запис автора 11 листопада 2006 р. у с. Поліське Коростенського р-ну Житомирської обл. від Башинської Марії Петрівни, 1926 р. н.

62 Жыццё і побыт беларусаў у прыкметах і павер'ях / Аўтары-ўкладныкы: В. С. Новак, А. А. Кастрыца, К. В. Паборцава; Гомельскі дзяржаўны ўніверсітэт імя Ф. Скарыны. Мінск: Права і эканоміка, 2014. С. 95.

63 Запис автора 7 вересня 2011 р. в с. Мелені Коростенського р-ну Житомирської обл. від Васянович Людмили Іванівни, 1951 р. н.

64 Запис автора 1 жовтня 2004 р. у с. Романівка Новоград-Волинського р-ну Житомирської обл. від Кубрак Ніни Василівни, 1926 р. н.

65 Запис автора 11 листопада 2006 р. у с. Поліське Коростенського р-ну Житомирської обл. від Жмаченко Катерини Тарасівни, 1936 р. н.

${ }^{66}$ Сусвет і прыродные стыхіі ў міфалагічнай традыцыі беларусаў / Аўтары-ўкладальнікі: В. С. Новак, А. А. Кастрица; Гомельскі дзяржаўны ўніверсітэт імя Ф. Скарыны. Мінск: Права і эканоміка, 2014. С. 81.

67 Запис атора 29 липня 2003 р. у с. Нове Залісся Бородянського р-ну Київської обл. від Романченко Ольги Василівни, 1941 р. н. та Потапенко Надії Петрівни, 1922 р. н., переселенок 3 с. Залісся Чорнобильського р-ну

68 Запис автора 1 липня 2003 р. у смт Чоповичі Малинського р-ну Житомирської обл. від Старченко Надії Володимирівни, 1935 р. н.

69 Запис автора 26 серпня 2003 р. у с. Хочине Олевського р-ну Житомирської обл. від Шинкар Варвари Олександрівни, 1935 р. н.

70 Жыццё і побыт беларусаў у прыкметах і павер'ях / Аўтары-ўкладныкы: В. С. Новак, А. А. Кастрыца, К. В. Паборцава; Гомельскі дзяржаўны ўніверсітэт імя Ф. Скарыны. Мінск: Права і эканоміка, 2014. С. 86.

71 Запис автора 1 серпня 2003 р. у с. Мироцьке Києво-Святошинського р-ну Київської обл. від Тигарькової Єфросини, 1929 р. н., Давиденко Марії Гнатівни, 1938 р. н. та Гаращенко Анастасії Несторівни, 1937 р. н.

72 Сусвет і прыродные стыхіі ў міфалагічнай традыцыі беларусаў / Аўтары-ўкладальнікі: В. С. Новак, А. А. Кастрица; Гомельскі дзяржаўны ўніверсітэт імя Ф. Скарыны. Мінск: Права $\mathrm{i}$ эканоміка, 2014. С. 78.

73 Запис автора 2 липня 2003 р. у с. Йосипівка Малинського р-ну Житомирської обл. від Марчук Єви Костянтинівни, 1926 р. н.

74 Запис автора 8 жовтня 2004 р. у с. Колки Дубровицького р-ну Рівненської обл. від Кутяш Серафими Федорівни, 1923 р. н.

75 Запис автора 3 квітня 2004 р. у с. Старий Дорогинь Народицького р-ну Житомирської обл. від Лаворчук Надії Іванівни, 1920 р. н.

76 Запис автора 9 жовтня 2004 р. у с. Немовичі Сарненського р-ну Рівненської обл. від Мельник Ганни Михайлівни, 1913 р. н.

77 Традыцыйная мастацкая культура беларусаў. У 6 т. Т. 6. Гомельскае Палессе і Паднепроўе. У 2 кн. Кн. 2 / А. М. Боганева [і інш.]. Мінск, 2013. С. 757.

${ }^{78}$ Беньковский И. Осина в верованиях и в понятии народа на Волыни // Киевская старина. 1898. № 7. C. 7-8.

79 Запис автора 8 жовтня 2004 р. у с. Колки Дубровицького р-ну Рівненської обл. від Кутяш Серафими Федорівни, 1923 р. н.

${ }^{80}$ Толстые Н. И. и С. М. Заметки по славянскому язычеству. 2. Вызывание дождя в Полесье // Славянский и балканский фольклор. Генезис, архаика, традиции. М.: Наука, 1978. С. 95-130.

81 Жыццё і побыт беларусаў у прыкметах і павер'ях / Аўтары-ўкладныкы: В. С. Новак, А. А. Кастрыца, К. В. Паборцава; Гомельскі дзяржаўны ўніверсітэт імя Ф. Скарыны. Мінск: Права і эканоміка, 2014. С. 130.

82 Запис автора 7 грудня 2002 р. у с. Мелені Коростенського р-ну Житомирської обл. від Васянович Ганни Андріївний, 1926 р. н.

${ }^{83}$ Традыцыйная мастацкая культура беларусаў. У 6 т. Т. 6. Гомельскае Палессе і Паднепроўе. У 2 кн. Кн. 2 / А. М. Боганева [і інш.]. Мінск, 2013. С. 1193.

84 Запис автора 1 липня 2003 р. у смт Чоповичі Малинського р-ну Житомирської обл. від Старченко Надії Володимирівни, 1935 р. н.

${ }^{85}$ Бондаренко Г. Обиденні та обітні рушники // Поетика і семантика українського рушника: образ, символ, знак (тези і різюме доповідей). К., 1997. С. 5. 